\title{
Sustainability, Civilization and Women- An Environmental Study of The Overstory by Richard Powers
}

\author{
Nikita Gandotra' \& Shuchi Agrawal ${ }^{2}$ \\ ${ }^{1}$ PhD scholar, Amity Institute of English Studies and Research, Amity University, Noida, \\ Uttar Pradesh, India. Email: nikitagandotra55@gmail.com \\ ${ }^{2}$ Associate Professor, Amity Institute of English Studies and Research, Amity University, \\ Noida, Uttar Pradesh, India.Email: sagarwal2@amity.edu
}

\begin{abstract}
The Overstory by Richard Powers is a reflection of the environmental issues gripping the human civilization once ozone depletion and global warming loomed into focus. Global warming and an intensive exploration of environmental effects on the human civilization have gained significance over time and they persist to be eminent topic of debate in both local and global context. While Emerson and Thoreau pay serious literary attention in nineteenth-century America; Robert Frost engages with ecology in the twentieth century. Likewise contemporary American literature reflects the conflicts that surfaced due to the industrial and technological moves affecting the environment. Richard Powers' novel forms an example how individuals and communities negotiate with these phenomena. There is nothing like Wordsworth and the English romanticists in fiction like The Overstory; there is nevertheless a romantic idealism in the characters whose engagement and commitment to environment and trees is portrayed by Powers. His reference to the Chipko movement is a gesture towards radical practical need and towards human commitment. Powers lets his character Mother $\mathrm{N}$ to affirm the strength of the Chipko women in India and the Kayapo Indians in Brazil, who stood up for trees. This strongly underlines the author's intention: women are central to civilization and sustainability. The paper aims to establish a relationship between sustainability and trees which symbolize life, and women who play a crucial role in sustaining both nature and civilization, in a sense, an ecofeminism.
\end{abstract}

Keywords: Richard Powers, The Overstory, Sustainability, Trees, Ecofeminism.

\section{Introduction}

Forest is a part of the ecosystem that plays a significant role in cultivating nutrition and conservation of biodiversity. Trees take care of greenhouse gas emissions which prevent global warming by absorbing carbon dioxide. But over time human activities have interfered with the environment causing significant changes in carbon dioxide level. According to an article "The Atmosphere: Getting a Handle on Carbon Dioxide - Climate Change: Vital Signs of the Planet" published on the official website of NASA, "the concentration of carbon dioxide in Earth's atmosphere is currently at nearly 412 parts per million (ppm) and rising. This represents a 47 percent increase since the beginning of the Industrial Age, when the concentration was near 280 ppm..." (Buis, 2020). In addition to the enhancement in carbon dioxide concentration, deforestation activities left forests with little room to fulfill their intended purpose. Environmental destruction has been at its height following industrialization and urbanization,

(C) AesthetixMS 2020. This Open Access article is published under a Creative Commons Attribution Non-Commercial 4.0 International License (http://creativecommons.org/licenses/by-nc/4.0/), which permits non-commercial re-use, distribution, and reproduction in any medium, provided the original work is properly cited. For citation use the DOI. For commercial re-use, please contact editor@rupkatha.com. 
with immense impact on ecosystems, livestock and people. There have been various such instances in which individuals have struggled in emerging and industrialized nations. In The Overstory, Richard Powers deals in large part with these questions about American environmentalism and its people, along with a few examples from India. Since the time of "Hebrews" and "Hesoid", individuals have always experienced an emergent need to preserve the environment; and even Plato remarked on "severe deforestation, and lamented the loss of fertile soil and defaced landscapes" (Wapner, 2010, p.39).

Humanity has grown at a pace which has led to irreversible environmental effects. All developing and developed countries are suffering in different ways because of this. To reduce rising inequality and achieve prosperity, the use of a large range of commodities in these nations needs to be put to equability. The consumption of "the earth's resources" by "an average American" is believed to be greater "than ... an average ecosystem dweller of the Third World" (Gadgil \& Guha, 2005, p.178). In The Overstory, Jorgen Hoel believes that the chestnut tree he has planted in his garden will be a source of play for his children as they will "shake the trunks and eat [its fruit] for free" (p.7). It is from such an expectation that we learn the vital environmental needs of humans. According to people like Hoel, their only wish is for "sustainable development" to ensure that the trees whose shade and fruits he had at his time would be enjoyed by his future generations too.

The giant trees of America known as Redwoods and dubbed as John Muir which were once considered its heritage after the 1850's started to be cut down. Such trees that the citizens previously admired for their immense height, greater life expectancy and the consistency of not being easily withered due to issues such as forest fires, etc., later became in their eyes a source of income. Starting from the county of Humboldt, these logging activities started to spread across the region, picking up a pace soon after World War II. The conifer species known as Douglas-fir which had been ignored earlier in contrast with redwoods had also been placed into use and made to disappear as the need for houses emerged after the war. In the novel, Powers deals with these species and their mass destruction, by observing which environmentalists came out as individuals or as groups in order to limit their cutting down.

Human civilizations have now consumed natural resources "twenty-two per cent beyond" the justified "sustainable levels" (Lamb, 2010). In such a situation, a desperate need exists for protecting the ecosystem for present and future generations alike. The environmentalist movements in America started to gush in the early nineteenth century, when it was thought that environmental degradation in turn resulted in contamination of air and water. The obvious consequences of damage to the environment may be seen in the romantic era through Wordsworth's writings and works by writers like “...Charles Dickens [who] wrote about the working and living conditions in the... [industries]" and Mary Shelly who talks of the cruel "machine world"... (Wapner, 2010, p.40). Powers also quotes Thoreau in The Overstory as he says "Old trees are our parents, and our parents' parents, perchance. If you would learn the secrets of Nature, you must practice more humanity..." (p.5). The novel's theme can be summarized across these few lines, where it becomes easy to estimate the zeal of the lead characters to save America's heritage trees and protect them on the stake of their own lives.

As the long-term debate about the need for sustainable use of the environment by civilization continues, it becomes important to highlight women's participation and role in these movements. The dedication of these women environmentalists started with small instances of planting trees in their backyard and showing their devotion to them. Many of them served as visionaries in the United States keen to protect the trees and animals, but the major credit for this 
went to men. The presence of women in environmental campaigns has been documented both in the First and Third world nations. Obviously, women and nature share similar concerns and must make common cause of shared concerns. The common factor may be seen as productivity and sustenance; hence the need to recognize the critical nature of women and environment for the survival of human civilization and the symbiosis of life on Earth.

\section{Environmental Movements by Women of the First and Third World Nations}

In the 1970s, W.A.R.N. (Women of All Red Nations) was founded by Native American women in the fight against uranium mining practices that had adverse environmental consequences and “...health concerns involving reproduction, specifically the fantastically high increase in miscarriages, birth defects, and childhood deaths due to cancer...” (Stein \& Unger, 2004, p.57). There is a comparable kind of passion among the female characters in The Overstory and an urge to be one with the environment and fight for the protection of America's declining heritage trees. Patricia Westerford, who works as a dendrologist, devotes her entire life to study the working of old trees and estimating the connection they form internally; demonstrating that they are "members of a community" (p.158). She asserts that these trees are "linked together in an airborne network, sharing an immune system.... [in which the] trunks are protecting each other" (p.158). Similarly, after experiencing death so closely due to electrocution, we find Olivia Vandergriff who was once a totally boisterous and resentful girl transforms into a calm and sacrificing personality. This incident ends up encouraging her to find a reason for her life in protecting trees, and on this path she said she was guided by the "...large, powerful, but desperate shapes... [which]...beckoned to her" (p.196). These creatures of light direct her thoughts and make her drive miles to see that "the most wondrous products of four billion years of life need help" (p.205).

Corresponding to the women's struggle in the United States, a worldwide revolution began in which small groups such as W.A.R.N. comprising women were led to stop the violence and abuse of trees. India was also witnessing these advancing moves brought in various sections by the environmental activists. One of them is the Chipko campaign, led by Indian women as the first step towards the ecofeminist rebellion. Terming the cycle as an 'ecological succession', as the redwoods and firs were eliminated from America, trees called kharik and banj were eliminated from the Himalayan forests promising to grow the commercial pine in order to fulfill economic desire in turn deteriorating the stability of these forests. This agitated the women who considered these trees as dear as their parental home. Vandana Shiva (1988) in her book Staying Alive: Women, Ecology and Survival in India points out how these women cling to trees for hours in order to shield them from inhumanity of males. Building on the ideas of "Mira Behn's ecological insights... Sunderlal Bahuguna who had worked with her in the Bhilangana valley" gave direction to the movement (Shiva, 1988, p.66). But eventually women's participation goes unnoticed in the struggle, as few male activists get more attention for their involvement.

\section{Unconditional Devotion of Women towards Trees}

Richard Powers embarks on the notion of masculinity that exists in America, which engulfs a respectable academician Patricia Westerford and discourages her from openly sharing her life's work, moving into wilderness, thus suppressing her emotions that she eventually reveals when summoned to court and rebukes the industrial world saying

If you want to maximize the net present value of a forest for its current owners and deliver the most wood in the shortest time, then yes: cut the old growth and plant straight-rowed replacement plantations, which you'll be able to harvest a few more times. But if you want next century's soil, if you want pure water, if you want variety and health, if you want 
stabilizers and services we can't even measure, then be patient and let the forest give slowly. (p.555)

This becomes a turning point where we see how women have acted in their own sacrificial way to protect the trees and Mother Earth not only in India but worldwide in different eras. The case of Olivia and Patricia, the ecofeminist image of Sita created by Nandini Sahu, shows the devotional character of women in different times towards their corresponding nature. Sita here says "My healing touch gave life to the dry grasses/ my tears gave the rivers full-bodied waters/ my music and songs added symphony and ambience" (Sahu, 2014, p.91). Here, we discover women and trees abandoned by the man centric culture's control of them and thus encouraging each other by being the pacifier for another in moments of torment. The depiction methods maybe different in terms of third world ecofeminist characters as compared to the first world, but we find that their purpose is the same, that is, promoting their concern for trees.

I do not fear your tyranny

I do not despair ever

for I guard one seed

a little live seed

That I shall safeguard

and plant again. (Shiva, 2013)

In these lines Vandana Shiva describes the battle of ladies in nations of the Third World where they have an exceptional link with trees and horticulture and how these women utilize their environmental resources in a sustainable way. Panhba, a Kayapo Indian woman in Brazil combats along with the people of her community to save the Amazonian forests which have been a home to her family since beginning, from destruction by the government. She realizes the necessity of these forests and says

If they cut down the trees now, there won't be air or nuts or fruits or animals left for my children and grandchildren. (Schipani, 2019)

Having experienced domination from the society's oppressive patriarchal structure, women like Panhba continue to struggle to protect trees without bothering to obtain any credits for their contribution. Men not only exhibited this kind of dominance over women but also over nature. Women have been depicted and romanticized historically as the one who sows the seed while she also cares for the children. She serves as the nurturer, creator and caretaker of her loved ones and nature.

\section{Struggle of Women in The Overstory}

In The Overstory we note that as a young girl Patricia begins to engage with trees and has a fondness for them. Soon just like her father, she also begins to understand their significance, which is why her father shares his thoughts on trees with her instead of her brothers and offers her Ovid's Metamorphosis on her birthday saying "For my dear daughter, who knows how big and wide the family tree really is" (p.147). When she grows older, she considers herself linked to trees and becomes dedicated to interacting alongside them as a group to figure out, show and explain their interconnectedness. She is rebuked during the journey of her research by the patriarchal society which considers her work as invalid. It pressures her to such a degree that she often avoids attempting to theorize her work and keeps it to herself while placing herself in the wild. Patricia's 
dedication can be compared to Thoreau's who says in his essay "Walking" that "give me a wildness whose glance no civilization can endure...", and it is believed that he wants a lonely life oblivious of human cultures (Thoreau \& Hyde, 2002). In fact Patricia like Thoreau is also able to study trees and stay among them because this is what brings a sense of peace to her. As she mentions that the tranquility experienced by Anne Frank during World War II at the sight of a chestnut "in [her] hopeless hiding" is incomparable to all other earthly pleasures (p.275).

Mimi Ma, a half Chinese engineer and another woman character in The Overstory becomes a tree activist after noticing the old trees' plight. Over the course of the book, we witness a change in her, and a sense of awareness peaks through her when battling with other reformists for the conservation of trees. Due to the odd circumstances in which she gets strangled after Olivia's death, she is compelled to live with an entirely different identity and during this time all she strives for is peace that can be summed up in the "calligraphic copy of Wang Wei's twelvehundred-year-old poem left unfurled on parchment across the desk in [her father's] study" before he died (p.50)

An old man, I want

only peace.

The things of this world

mean nothing.

I know no good way

to live and I can't

stop getting lost in my

thoughts, my ancient forests...(p.50, 51)

Mimi Ma always yearned for this kind of peace and is noted as a woman who shows her devotion to trees and eventually takes on the persona of an unlicensed therapist with a presumed name. Her path can be compared to the Indian Prince Siddhartha as portrayed in Herman Hesse's novel Siddhartha where this rich Brahman renounces the materialistic world and procures a saintly life. Having left "his bygone life .... He had [finally] come to his senses by a river, under a coconut tree" (Hesse, 1922, p.79). Mimi too derives her happiness leaning against the pines of San Francisco.

Olivia, who is the 'Erin Brockovich' of The Overstory, changes her role from being a girl with tumultuous feelings to a woman with modeled altruistic behavior. Erin discovered the poisoning of water in Hinkely by Pacific Gas and Electric Company, and promptly brought a lawsuit against them. Olivia also felt the decay of the old growth trees as shown to her by the creatures of light, which ignited in her a desire to preserve these heritage trees. Not only did this girl live among the trees for more than a year, but she also appealed to the men around her to understand the damage done to these trees and the need to stand up for them. During this journey, she starts to encounter life like characteristics of trees gradually and progressively as also the researcher Patricia Westerford describes in her book The Secret Forest

You and the tree in your backyard come from a common ancestor. A billion and a half years ago, the two of you parted ways. But even now, after an immense journey in separate directions, that tree and you still share a quarter of your genes... (p.166)

It was with the women such as Wangari Maathai and many others from the third world that the awareness got created suggesting that the colonization took place not just for the nation 
and its inhabitants but also for the trees. Being a woman and having witnessed the activities in which her mother was involved, and for which she was required to gather firewood, gave her consciousness regarding the vital essence of such trees in their lives. She could see through the imperialism that by chopping down these trees the wealthy got wealthier, while the citizens in her society were excluded from these vital goods. Therefore, she started the Green Belt Campaign planting many trees; she was also beaten up during this cycle and placed in jail as did Olivia suffered fighting against government officials and Humboldt industry employees. In this battle against the demons of humanity who behave as the persecutors of trees; a woman like Olivia, who is the true feminine image of nature, attempts to defend it as her own sister, but is sadly killed. Out of the male partners who assist her in the preserving of trees, Adam turns to his patriarchal impulses, and instead of supporting her in the moment of suffering, he can only think of the futility of this endeavor that he took part in. The man in him makes him believe in the utter destruction of everything huge that he had worked for considering it meaningless, and thinking that in the end "Earth [has to] be monetized until all trees grow in straight lines..." (p.434, 435). Whereas, Olivia till her last breath believes in the imperishable nature of the five elements most pre Christian cultures believed in. These elements correspond to Earth, water, light, air and space (they are imperishable in a scientific sense but matter and energy are always conserved);

For you have five trees in Paradise

which do not change,

either in summer or in winter,

and their leaves do not fall.

He who knows them

shall not taste of death. (p.435)

\section{Conclusion}

Sustainability is the fundamental essence of existence which comes from the God of Sustenance. Sustenance is the same as it seeks to satisfy and maintain our need for food and nutrition, bearing into consideration that these items are stored in adequate amounts for our future generations too. Central to the sustenance of life on Earth is the environment as seen in the form of trees and women, who choose to preserve and nurture it in exactly the same way. Women have a larger interest in environmental protection relative to man who just aims at commercial and technological aspects of it. We observe that the overall attitude of society and controlling power like men have never been appreciative of the link between women and environment. Men are rooted in forces such as capitalism and globalization that lead together to domination of women and nature. These two problems are directly connected and will continue to function to destroy the environment and trees. However, the issue is generally dealt with in reductive conceptualism, for instance capitalism versus ecofeminism i.e. an antagonistic connection between man's understanding of economic prosperity and environmental good sense related to women who struggle for sustainability. And it's mostly dealt with under the banner of capitalism versus ecofeminism, which is related to women who struggle for sustainability more closely. The Overstory is an episodic narrative that takes some historical facts and much from ecological thoughts giving it a semi-fictional structure.

\section{References}


Buis, Alan. (2020, March 3). The Atmosphere: Getting a Handle on Carbon Dioxide - Climate Change: Vital Signs of the Planet. NASA. https://climate.nasa.gov/news/2915/the-atmosphere-getting-a-handle-oncarbon-dioxide/.

Gadgil, Madhav. \& Guha, Ramachandra. (2005). Ecology and equity: the Use and Abuse of Nature in Contemporary India (p. 178). Routledge.

Genecov, Max. (2020, September 4). The 'Erin Brockovich' town is still toxic (and nearly abandoned). Grist. https://grist.org/science/the-true-story-of-the-town-behind-erin-brockovich/.

Hesse, Hermann. (1922), \& Neugroschel, Joachim. (2003). Siddhartha (p. 79). Penguin Books.

Lamb, Robert. (2010). What is civilization's impact on Earth's environment? HowStuffWorks. Retrieved 7 August 2020, from https://science.howstuffworks.com/environmental/conservation/issues/civilization-impactenvironment.htm

National Park Service. (PDF). Sequoia and Kings Canyon . California, U.S. Retrieved 19 october 2020, from https://www.nps.gov/seki/planyourvisit/upload/Text_Side_SEKI12139Fo1_updated.pdf

Powers, Robert. (2019). The Overstory. Penguin Random House UK.

Sahu, Nandini. (2014). Sita (A Poem) (p. 91). The Poetry Society of India.

Schipani, Andres. (2019). Brazil's rainforest warriors ready to battle Bolsonaro. Ft.com. Retrieved 17 August 2020, from https://www.ft.com/content/7aoa661c-558b-11e9-91f9-b6515a54c5b1.

Shiva, Vandana. (1988). Staying Alive (p. 65-66). Zed Books.

Shiva, Vandana. (2013). THE SEED KEEPER. Seed Freedom. Retrieved 17 August 2020, from https://seedfreedom.info/the-seed-keeper/.

Stein, Rachel, \& Unger, Nancy C. (2004). Women, Sexuality, and Environmental Justice in American History. In New perspectives on environmental justice: gender, sexuality, and activism (pp. 56-57). Rutgers University Press.

Sydee, Jasmin, \& Beder, Sharon. (2001). Ecofeminism and Globalism. University of Wollongong Australia. https://documents.uow.edu.au/ /sharonb/ecofeminism.html.

Thoreau, Henry David, \& Hyde, Lewis. (2002). The Essays of Henry D. Thoreau. Google Books.

https://books.google.co.in/books/about/The_Essays_of_Henry_D_Thoreau.html?id=75dtDQx

AIC.

Wapner, Paul. (2010). Living Through the End of Nature - The Future of American Environmentalism (p.39,40). MIT Press.

Wilson, Paul G. (2001). "The Legacy of the Log Boom Humboldt Count Logging from 1945 to 1955”. Humboldt Digital Scholar.

https://humboldtdspace.calstate.edu/bitstream/handle/10211.3/132765/Wilson_Paul_Barnum_otf.pdf? sequence $=1$ 